AC 2012-5161: STUDY OF THE STUDENTS OF A SUMMER 2007 ENGINEERING BRIDGE PROGRAM

Dr. William Berg, University of Texas, Brownsville 


\section{Study of the students of a summer 2007 Engineering Bridge program}

Introduction

In the summer of 2007, a summer engineering bridge program was presented by the Engineering Department of The University of Texas at Brownsville and Texas Southmost College

(UTB/TSC), an institution which serves a region where opportunities for higher education has been limited and where the proportion of the population with bachelors degrees, and in particular with engineering and science degrees, is lower than the average in the country. The summer program was created to prepare students for an engineering education and to ease the "paradigm shift" from high school, where the mission is to graduate a captive audience of students, to college, where the mission is to prepare volunteer students for professions, arts, or academia.

The math and science foundation received in public school by our incoming engineering freshmen was perceived by the Engineering Department faculty as weak, and it was causing problems for the students, who struggled through math and science courses. In fact, the perception was correct. Texas did not require four years of science and math for college-bound high school graduates until the incoming high school freshman class of 2007-08. That initial cohort graduated from high school in 2011.

\section{Program Description}

The summer program included three components: Introduction to Engineering, Mathematics for Engineers, and History of Science and Engineering.

Introduction to Engineering was the equivalent of the standard Freshman Introduction to Engineering course. The luxury of summer, with no other course activity in the department, allowed us to include lectures from electrical engineering faculty on circuits and from mechanical engineering faculty on statics. There was "flight" day, on which the students watched and manipulated an instrumented airfoil in the department wind tunnel through fly and stall and recover. This activity was followed by a field trip to the Brownsville airport, where the students observed planes landing and taking off. The day was completed with a visit to the adjacent Flight Museum, where the students got to see old planes, biplanes, and WWII planes and observe the control surfaces operated by museum staff.

The Mathematics for Engineers course included most elements of a standard Precalculus course presented from an engineering standpoint, with emphasis on applications. The first required mathematics course in the Engineering Physics degree program is Calculus I. Its prerequisite is precalculus. The Mathematics Department offered a test for students who had taken calculus or precalculus in high school to ascertain that they were adequately prepared for college Calculus I. Success on the test gained entry to Calculus I. Partial success allowed entry to Precalculus, bypassing College Algebra, its prerequisite. The test consisted of four computer generated sections, with students allowed up to one hour for each section, and breaks between sections. Some students could complete all four sections in about an hour.

Since half of the anticipated students were Mexican nationals, with limited English communication skills, a course in English was indicated. The Mexican students had two to four 
years of English courses in high school, but were uncomfortable with conversation. Since the other half of the anticipated students were Mexican-Americans, we wished to avoid boring them while keeping them together in the same learning environment. A course was designed around engineering video entertainment. We used the History Channel program "Engineering an Empire," which gave mass-audience-level lessons in the history of engineering. All the students were interested and fascinated by the engineering accomplishments of ancient Egypt, Greece, Macedonia, Phoenicia, Rome, Byzantium, and China. There was particular interest in and identification with the feats of the Aztecs and the Mayans, whose civilizations were only a few hundred miles from Brownsville. We also used "An Inconvenient Truth," Al Gore's Global warming movie.

Each meeting of the History of Science and Engineering course included part of a video, followed by discussion and a review of vocabulary, followed by a vocabulary homework assignment. Everyone learned new terms such as causeway, siege engine, floating bridge, pilings, aqueduct, triangulation, canal locks, etc. During the following years, the Mexican students referred to the course as their launching into conversational English, although they always spoke Spanish among themselves.

The program was free to the students. Instructors were paid from a discretionary fund under the control of the Dean of Science, Mathematics, and Technology. Students were not given credit for Introduction to Engineering until they enrolled in and paid for the course in the fall. They received their grade for the summer course at the end of the Fall semester. Attendance requirements for Introduction to Engineering the fall semester were waived.

Student Profile and Recruiting

The University of Texas at Brownsville and Texas Southmost College was a partnership of a university and a community college, a "community university" which served Brownsville. Thus, the institution was an open university. The Engineering Department faculty discovered that the main difference between students admitted to a selective post-secondary Engineering school and those who enroll in an open Engineering School is preparation, motivation, and cognizance of the role of the student in student success. (In 2010, the Texas Southmost College Board of Trustees voted not to continue the partnership and the University of Texas System Chancellor sent a letter dissolving the partnership to be complete by August 31, 2015.)

Well over $90 \%$ of the student population is Hispanic. Over $50 \%$ of the students are first generation college students in their families, and over 30\% are first generation high school graduates. Over $50 \%$ of students entering UTB/TSC were not college-ready in reading, writing or mathematics, according to results of the COMPASS test, a product of ACT, Inc. The Engineering Department active student population was at a higher academic level than the general student population because a student could not take any course in any of our programs without having completed College Algebra. A small number of active students did have problems with English proficiency.

One hundred per cent of the students in the Engineering Summer Bridge program were Hispanic. The class consisted of Mexican-Americans and Mexican nationals. Three, from Homer Hanna high school, were about to enter their senior year. The rest were high school graduates. 
In Mexico, free and open public education ends at eighth grade. High schools are either private or they are state technical training schools. The technical schools as well as the high schools included mathematics through integral calculus and they included a year of physics. At the time Texas high schools did not have a math requirement or a science requirement for graduation. Now they do. All students graduating high school since 2011 will have taken four years of math and four years of science.

The Engineering Department had experience with an exceptionally well prepared cohort of students in the class of 2003. They outshone their American classmates in every course. They were the source of the belief in the department that products of Mexican high schools would excel in engineering programs here. The department recruited at both private high schools and state technical high schools in H. Matamoros, Tamaulipas, the Mexican sister city across the Rio Grande from Brownsville, Texas. It was learned that one of the Brownsville schools, Hanna High School, would provide lunch for the class if UTB/TSC would accept students who had only completed eleventh grade.

In the tables below, CBTIS is the abbreviation for a Mexican technical high school system, Centro de Bachillerato Tecnologico Industrial y de Servicios. Students from two CBTIS schools in Matamoros were recruited. There was also a student from Centro Estudios Tecnologicos Industrial y de Servicios (CETIS) 71 in Reynosa, the next city up river about 60 miles.

Although there was room for twenty students, only fourteen students participated in the program. 
Table 1. Progress of students 1-4 through the summer program and college showing Semester gpa/Cumulative gpa and other pertinent information.

\begin{tabular}{|c|c|c|c|c|}
\hline ID & 1 & 2 & 3 & 4 \\
\hline $\mathrm{HS}$ & Hanna & Porter & CBTIS 189 & CBTIS 189 \\
\hline Country & US & US & Mexico & Mexico \\
\hline Entering & HS Grad & HS Grad & HS Grad & HS Grad \\
\hline SP 2006 & $4.000 / 4.000$ & & & \\
\hline FA 2006 & $3.700 / 3.769$ & & & \\
\hline SP 2007 & $3.000 / 3.526$ & $4.000 / 4.000$ & & \\
\hline \multicolumn{5}{|l|}{ S1 2007} \\
\hline \multicolumn{5}{|l|}{ S2 2007} \\
\hline SU 2007 & Intro to Eng (A) & No Grade & & Intro to Eng (B) \\
\hline Start Math & Calculus I & $\begin{array}{l}\text { HS Alg } \\
\text { HS Reading }\end{array}$ & & Precalc \\
\hline FA 2007 & $\begin{array}{l}\text { BS Engineering } \\
\text { Physics } \\
\quad 3.167 / 3.387\end{array}$ & $\begin{array}{l}\text { BS.Electrical } \\
\text { Engineering Tech } \\
2.500 / 2.875\end{array}$ & Did not Start & $\begin{array}{l}\text { BS Engineering } \\
\text { Physics } \\
0.429 / 0.429\end{array}$ \\
\hline SP 2008 & $2.500 / 3.140$ & $1.846 / 2.414$ & & $1.385 / 1.412$ \\
\hline FA 2008 & $2.385 / 2.964$ & $1.667 / 2.469$ & & Withdrawn \\
\hline SP 2009 & $1.786 / 2.729$ & $\begin{array}{l}\text { BS Criminal } \\
\text { Justice } \\
0.500 / 2.000 \\
\end{array}$ & & \\
\hline FA 2009 & $2.412 / 2.667$ & $0.000 / 1.580$ & & \\
\hline SP 2010 & $1.154 / 2.546$ & $\begin{array}{l}\text { Academic } \\
\text { Suspension }\end{array}$ & & \\
\hline SU 2010 & $1.000 / 2.485$ & & & \\
\hline FA 2010 & $2.250 / 2.514$ & $2.000 / 1.700$ & & \\
\hline SP 2011 & $2.750 / 2.613$ & $0.000 / 1.604$ & & \\
\hline S1 2011 & $4.000 / 2.685$ & & & \\
\hline S2 2011 & $3.000 / 2.721$ & & & \\
\hline FA 2011 & $1.500 / 2.590$ & Withdrawn & & \\
\hline \multicolumn{5}{|l|}{ SP 2012} \\
\hline \multicolumn{5}{|l|}{ FA 2012} \\
\hline SP 2013 & To graduate & & & \\
\hline & & & & \\
\hline & & & & \\
\hline
\end{tabular}

Student 3 completed the summer program but never started the course. Every day of the course he said he needed money to go to college, but since there is no financial aid for foreign nationals, he was unable to register. 
Table 2. Progress of students 5-8 through the summer program and college showing Semester gpa/Cumulative gpa and other pertinent information. High School Dual Enrollment is indicated by DE.

\begin{tabular}{|c|c|c|c|c|}
\hline ID & 5 & 6 & 7 & 8 \\
\hline HS & Hanna & Hanna & La Salle & CETIS 71 \\
\hline Country & US & US & Mexico & Mexico \\
\hline Entering & Senior & Senior & HS Grad & HS Grad \\
\hline \multicolumn{5}{|l|}{ Semester } \\
\hline FA 2005 & $4.00 / 4.00 \mathrm{DE}$ & $4.00 / 4.00 \mathrm{DE}$ & & \\
\hline FA 2006 & $4.00 / 4.00 \mathrm{DE}$ & $4.00 / 4.00 \mathrm{DE}$ & & \\
\hline SP2007 & $4.00 / 4.00 \mathrm{DE}$ & & & \\
\hline SU 2007 & & & Intro to Eng (A) & Intro to Eng (A) \\
\hline FA 2007 & 4.00/4.00 DE & $3.571 / 3.727$ & $\begin{array}{l}\text { AA General Stud. } \\
\text { Precalculus } \\
1.500 / 1.500\end{array}$ & $\begin{array}{l}\text { BS Electronic } \\
\text { Engineering } \\
\text { Technology } \\
\text { Calculus I } \\
\quad 1.643 / 1.643 \\
\end{array}$ \\
\hline SP 2008 & $4.00 / 4.00 \mathrm{DE}$ & $3.000 / 3.571$ & $\begin{array}{c}\text { BS Engineering } \\
1.000 / 1.147\end{array}$ & Withdrawn \\
\hline FA 2008 & $\begin{array}{l}\text { BS Computer } \\
\text { Science } \\
4.00 / 4.00 \\
\end{array}$ & \begin{tabular}{|l|} 
BS Computer \\
Science \\
$4.000 / 3.733$ \\
\end{tabular} & $\begin{array}{l}\text { Academic } \\
\text { Suspension }\end{array}$ & \\
\hline SP 2009 & $3.533 / 3.876$ & $2.667 / 3.467$ & $\begin{array}{l}\text { BS Computer } \\
\text { Science } \\
3.000 / 1.733\end{array}$ & \\
\hline S1 2009 & $4.00 / 3.881$ & & & \\
\hline S2 2009 & $3.00 / 3.839$ & & & \\
\hline FA 2009 & $3.625 / 3.795$ & $3.800 / 3.533$ & $1.625 / 1.794$ & \\
\hline SP 2010 & $4.000 / 3.830$ & $4.000 / 3.615$ & $\begin{array}{l}\text { Academic } \\
\text { Suspension }\end{array}$ & \\
\hline FA 2010 & $3.438 / 3.773$ & $3.375 / 3.654$ & $\begin{array}{l}\text { AS Computer } \\
\text { Science } \\
3.500 / 2.050\end{array}$ & \\
\hline SP 2011 & $4.000 / 3.800$ & $3.800 / 3.672$ & $\begin{array}{r}\text { BA Psychology } \\
3.333 / 2.286 \\
\end{array}$ & \\
\hline S1 2011 & & & $3.000 / 2.364$ & \\
\hline FA 2011 & $3.769 / 3.797$ & $4.000 / 3.698$ & $3.000 / 2.453$ & \\
\hline SP 2012 & To graduate & To graduate & Reg for $7 \mathrm{CH}$ & \\
\hline \multirow{2}{*}{\multicolumn{5}{|c|}{$\begin{array}{l}\text { FA } 2012 \\
\text { SP } 2013\end{array}$}} \\
\hline & & & & \\
\hline SP 2015 & & & To graduate & \\
\hline & & & & \\
\hline
\end{tabular}

Student 5: Took Dual Enrollment Precalculus in Fall 2005. Freshman in Fall 2008 in B.S. 
Computer Science program. Plans to graduate in Spring 2012.

Student 6: Took Dual Enrollment Precalculus in Fall 2005. Freshman in Fall 2008 in B.S. Computer Science program. Plans to graduate in Spring 2012.

Student 7: Seems to have found his niche in Psychology. However, has only take one upper division course. Needs 33 more hours of upper division courses and 20 hours of lower division courses to graduate.

Student 8: Completed only one semester. Accepted into Calculus I but then earned "D".

Table 3. Progress of students 8-12 through the summer program and college showing Semester gpa/Cumulative gpa and other pertinent information.

\begin{tabular}{|c|c|c|c|c|}
\hline ID & 9 & 10 & 11 & 12 \\
\hline HS & Hanna & Hanna & CBITS 135 & La Salle \\
\hline Country & US & US & Mexico & Mexico \\
\hline Entering & HS Senior & HS Grad & HS Grad & HS Grad \\
\hline \multicolumn{5}{|l|}{ Semester } \\
\hline FA 2005 & & $3.000 / 3.000$ & & \\
\hline FA 2006 & & $3.000 / 3.000$ & & \\
\hline SU 2007 & & Intro to Eng (A) & Intro to Eng $(\mathrm{A})$ & \\
\hline FA 2007 & $3.700 / 3.700$ & $\begin{array}{l}\text { BS Engineering } \\
\text { Calculus I } \\
2.267 / 2.560\end{array}$ & $\begin{array}{l}\text { BS Engineering } \\
\text { Calculus I } \\
2.571 / 2.571\end{array}$ & $2.857 / 2.857$ \\
\hline SP 2008 & $3.700 / 3.700$ & $1.867 / 2.300$ & $2.733 / 2.655$ & $1.714 / 2.286$ \\
\hline S1 2008 & & & $2.000 / 2.576$ & $3.250 / 2.406$ \\
\hline S2 2008 & & & & $4.000 / 2.583$ \\
\hline FA 2008 & $\begin{array}{l}\text { BS Physics } \\
\text { Calculus I } \\
3.765 / 3.730\end{array}$ & $2.500 / 2.357$ & $3.357 / 2.809$ & $2.857 / 2.660$ \\
\hline SP 2009 & $2.867 / 3.481$ & $1.929 / 2 . .271$ & $2.167 / 2.678$ & $2.071 / 2.531$ \\
\hline S1 2009 & & $3.000 / 2.311$ & $3.000 / 2.708$ & \\
\hline FA 2009 & $3.000 / 3.379$ & $0.846 / 2.167$ & $2.615 / 2.692$ & $2.063 / 2.438$ \\
\hline SP 2010 & $2.929 / 3.300$ & $0.462 / 1.938$ & $3.462 / 2.802$ & $1.692 / 2.411$ \\
\hline S1 2010 & & $2.000 / 1.970$ & $3.000 / 2.776$ & $2.000 / 2.468$ \\
\hline S2 2010 & & $2.571 / 2.010$ & $3.000 / 2.782$ & $2.000 / 2.454$ \\
\hline SU 2010 & & & $2.000 / 2.768$ & $3.000 / 2.436$ \\
\hline FA 2010 & $3.077 / 3.326$ & $1.750 / 2.064$ & $1.769 / 2.667$ & $1.154 / 2.364$ \\
\hline SP 2011 & $3.412 / 3.392$ & $1.692 / 2.152$ & $2.889 / 2.683$ & $2.625 / 2.445$ \\
\hline FA 2011 & $3.727 / 3.425$ & $0.500 / 1.992$ & $2.300 / 2.736$ & $2.688 / 2.624$ \\
\hline SP 2012 & To graduate & & To graduate & To graduate \\
\hline \multicolumn{5}{|l|}{ FA 2012} \\
\hline SP 2013 & & Possible grad & & \\
\hline SP2015 & & Possible grad & & \\
\hline & & & & \\
\hline
\end{tabular}

Student 10: Is struggling through his major. He has only $18 \mathrm{CH}$ remaining, but his past performance indicates he may not complete until Spring 2015. 
Table 4. Progress of students 13-14 through the summer program and college showing Semester gpa/Cumulative gpa and other pertinent information.

\begin{tabular}{|l|l|l|}
\hline ID & 13 & 14 \\
\hline HS & CBTIS 135 & Porter \\
\hline Country & Mexico & US \\
\hline Entering & HS Grad & HS Grad \\
\hline Semester & & $\begin{array}{l}\text { BS Engineering } \\
\text { Physics }\end{array}$ \\
\hline SP 2007 & A Intro to Eng & \\
\hline SU 2007 & $\begin{array}{l}\text { BS Engineering } \\
1.929 / 1.929\end{array}$ & \\
\hline FA 2007 & $2.250 / 2.077$ & \\
\hline SP 2008 & $3.625 / 2.441$ & BS \\
\hline S1 2008 & & Manufacturing \\
& Eng Tech \\
\hline FA 2008 & $2.571 / 2.479$ & \\
\hline SP 2009 & $2.286 / 2.435$ & \\
\hline S1 2009 & $3.000 / 2.554$ & \\
\hline S2 2009 & $4.000 / 2.676$ & \\
\hline FA 2009 & $3.462 / 2.864$ & \\
\hline SP 2010 & $3.375 / 3.043$ & \\
\hline S1 2010 & $3.000 / 3.077$ & \\
\hline SU 2010 & $4.000 / 3.082$ & \\
\hline FA 2010 & $3.375 / 3.117$ & \\
\hline SP 2011 & $3.083 / 3.114$ & \\
\hline FA 2011 & & \\
\hline SP 2012 & & \\
\hline FA 2012 & & \\
\hline SP 2013 & & \\
\hline & & \\
\hline & & \\
\hline Stuated & & \\
\hline
\end{tabular}

Student 13: Graduated in Spring 2011 after 4 years.

Student 14 Took six courses unrelated to each other nor to any major. Three were taken as Dual Enrollment (DE) in high school and the others taken in summers after high school graduation.

Results

The first student from the 2007 summer program to graduate graduated with a B.S. degree in Engineering Physics - Electrical specialization in May, 2011, four years after starting. Five more students are planning to graduate by May 2012, two with Engineering degrees after five years, two with Computer Science degrees after 4 years, and one with a Physics degree after 4 years. In total, six Bachelor of Science degrees will have been awarded within five years of starting. Table 
5 shows these students.

Two more students will graduate with an engineering degree in May 2013. A ninth student is now a Psychology major with an anticipated graduation date of 2015. Table 6 display this information.

Three students withdrew after having been unsuccessful at college work. One student never started at UTB/TSC for lack of funds. The fourteenth student may have gone to college elsewhere; he left no tracks.

The other three dropped out of college by the end of the 2008-2009 academic year.

Table 5. Students completing Bachelor degrees by Spring 2012

\begin{tabular}{|c|c|c|c|}
\hline Student & BS Degree & Semester & Years to BS \\
\hline 5 & Computer Science & May, 2012 & 4 \\
\hline 6 & Computer Science & May, 2012 & 4 \\
\hline 9 & Physics & May, 2012 & 4 \\
\hline 11 & Engineering & May, 2012 & 5 \\
\hline 12 & Engineering & May, 2012 & 5 \\
\hline 13 & Engineering & May, 2011 & 4 \\
\hline
\end{tabular}

Table 6. Students completing Bachelor degrees after Spring 2012

\begin{tabular}{|c|c|c|c|}
\hline Student & Degree & $\begin{array}{c}\text { Anticipated } \\
\text { Semester }\end{array}$ & Years to BS \\
\hline 1 & BS Engineering & May, 2013 & 6 \\
\hline 10 & BS Engineering & $\begin{array}{c}\text { May, 2013 to } \\
\text { May 2015 }\end{array}$ & 6 to 8 \\
\hline 9 & BA Psychology & May, 2015 & 8 \\
\hline
\end{tabular}

Lessons Learned

The summer program is a time for transitions for students. For some, it included commuting every day across the border. For most, there was a first taste of college expectations. For those not eligible for financial aid, or for enough financial aid, there was the challenge of finding funding for college.

Only one student successfully passed the math exam to waive Precalculus. The others did well enough to enter Precalculus. More opportunities to practice math with an objective of retaining the math learned may be useful. Merely providing an engineering context for the math was not enough.

Pizza was provided every Friday for faculty and students. This weekly party lunch provided an environment for informal interaction among faculty and students. This provided a foundation of mutual respect. The warm relationship persisted and grew for the college careers of the students who stuck with Engineering.

Discussions and exercises following the history of engineering videos also helped students 
develop lasting academic relationships as discussions were non-competitive, non-threatening, and the subject matter was broad, deep and equally new to all. Thus, there was more value to the course than merely English practice.

The students who showed no strong inclination to do homework during the Summer Bridge also showed no strong inclination to do so after beginning college and were in a constant struggle to pass courses until they had to drop out or until the rigors of the engineering program drove them to other majors.

Three students who took the summer bridge program while still in high school were excellent students but were never engineering students nor did they ever intend to be. Careful screening could prevent this from recurring in the future.

Afterword

Difficulty in obtaining funding and a drive to ABET accreditation of the program prevented a repeat of the program. However, lessons learned were frequently discussed among the faculty and with the students.

A U.S. Department of Education grant aimed at improving minority access to STEM degrees was awarded to [the university] in Fall 2011. Some of these funds are being used for a repeat of the Engineering Summer Bridge in the summer of 2012 incorporating lessons learned. 